\title{
Unequal internationalisation and the emergence of a new epistemic community: gender and migration
}

\author{
Eleonore Kofman
}

Correspondence: e.kofman@mdx.ac.
uk

Middlesex University, London, UK

\begin{abstract}
In this contribution to the formation of an epistemic community and its knowledge production developed in the Paper Between fragmentation and institutionalisation: the rise of migration studies as a research field, I seek to go beyond the bibliometric analysis, and in particular explore the nature of its internationalisation, the connections authors have across the globe and the unequal valuation of differently located research. These aspects underpin networks in the formation and evolution of epistemic communities. I shall illustrate my points through an epistemic community which has grown significantly in the past two decades, but scarcely gains a mention in the Paper. Gender and migration can be placed within the much broader cluster of globalisation, and especially in more recent years, transnationalism. My analysis does not start from bibliometric measures, which I do not have, but is based on selected reviews at different stages of the emergence of this field and my own involvement in it since the early 1990s.
\end{abstract}

Keywords: Gender, migration, knowledge production, epistemic community

In the Paper (Levy, Pisarevskaya, \& Scholten, 2020), the internationalisation of migration studies is traced through cross-country collaboration, especially the extent of coauthorship, yet the measurement of internationalisation goes beyond co-authorship. It could include the extent to which we cite each other ie. self referentiality, and to what extent we use the theoretical, conceptual and methodological insights developed by others. As the paper states "Global inequalities of knowledge production may have played a role in different levels of internationalisation (p.16)". In relation to the latter, we need to take into account the power relations between Northern and non Northern scholars, institutions and publications, and often between Northern scholars as well.

The circulation of scholars from postgraduate students to researchers may in part explain or be the context for co-authorship. Most of the circulation takes place from South to North. Co-authorship is more likely for postgraduates from the South who have attended elite institutions in North America and Europe. Yet for many scholars from the South attendance at conferences and workshops, in which knowledge circulates, may be beset by strictures of funding and visa regimes. For some, the circulation of people and knowledge reflects older colonial links and shared linguistic competence.

(c) The Author(s). 2020 Open Access This article is licensed under a Creative Commons Attribution 4.0 International License, which permits use, sharing, adaptation, distribution and reproduction in any medium or format, as long as you give appropriate credit to the original author(s) and the source, provide a link to the Creative Commons licence, and indicate if changes were made. The images or other third party material in this article are included in the article's Creative Commons licence, unless indicated otherwise in a credit line to the material. If material is not included in the article's Creative Commons licence and your intended use is not permitted by statutory regulation or exceeds the permitted use, you will need to obtain permission directly from the copyright holder. To view a copy of this licence, visit http://creativecommons.org/licenses/by/4.0/. 
For example, beyond English, there are continuing links to the colonial heartland among French, Spanish and Portuguese scholars. At the same time, researchers from the North may in particular focus on flows of migrants from former colonies in the South and the return of these migrants (Cortes and Oso 2017) and, in undertaking such research, develop links with institutions in the South.

In the South, however, there are relatively few institutions which host scholars, though in recent years development aid has funded selected institutions which have benefited from substantial research funding, for example in Ghana (British, Dutch) and in Uganda (British). For example, the UK Research and Innovation Global Challenges Fund has invested large sums of money, especially in low income countries. In Asia, on the other hand, the Asian Migration cluster of the Asian Research Institute at the National University of Singapore, initiated in 2001, has collaborated with scholars on projects, widely disseminated its publications and hosted scholars from around the world.

The publishing industry too plays a part. Consolidation of a few large publishers, especially in journal publication, such as Sage, Springer, Taylor and Francis, have extended internationalisation but their headquarters are located in the North. Just as there are relatively few major institutions in the South, there are few well known migration journals and less coverage by the Web of Science of these journals. A partial exception has been The Asian and Pacific Migration Journal, an English-language journal founded in 1992 by the Scalabrini Centre in Manila, and publishing path-breaking theoretical articles on family migration (Zlotnik 1995) and international social reproduction (Truong 1996). It is now published by Sage. And where one publishes and in what language makes a difference to whether one's research is cited by others. The politics of translation means that little is translated into English.

Whilst the above aspects can be captured to some extent through bibliometric analysis, other dimensions of how knowledge circulates reflect the power relationship between North and South. The Paper notes that internationalisation is uneven and depends on varied levels of internationally-oriented research policies and global inequalities of knowledge production. Since the 1990s, feminist scholars have struggled with the bifurcation of the North as the centre of theoretical endeavours and production of valid knowledge about the world and the South as the source of empirical studies. As Connell (2014), writing of the marginalisation of theory produced in the South, argued "Almost all the feminist thought that circulates internationally and addresses economic or cultural globalization is based on concepts and methods developed in the global North... The centre produces theory, the periphery data and politics". Connell's critique echoes the call for an epistemic decolonisation of migration theory to overcome the epistemic division between knowledge produced by Western subjects, which is a priori superior to the knowledge produced by non-Western colonial subjects, and which reproduces a northern centric social science (de Sousa Santos 2014; Quijano 2000). We need to problematise our theorizations in order to challenge the universalism of Eurocentric theories (Raghuram and Madge 2006) and recognise that engaging with Southern theorizations may not be simple. It requires thinking how knowledge produced in the South circulates and is articulated by us (Halvorsen 2018).

Obviously this has a bearing on the formation and configuration of an epistemic community where sites of knowledge production are inevitably located in the North. Nonetheless, we should enquire to what extent scholars outside the dominant hubs 
participate and contribute theoretically to epistemic communities. And to what extent do migration scholars in the North cite those in the South, not just for their empirical data but also for their theoretical insights?

I shall illustrate these points through the development of a new epistemic community, the sub-field of gender and migration, in which a network of scholars has emerged over the past two to three decades. In the Paper, epistemic communities and their evolution are identified through co-citation analysis. Bringing together research through institutional developments such as the Standing Committee on Gender, Generation and Age (2004-2009) in IMISCOE, and research or study groups in international disciplinary organisations, such as the International Geographical Union, International Sociological Association, and the Council of European Studies has enabled researchers to meet, publish collaboratively or prepare research grant proposals. Gender and migration as an epistemic community has had national contours, often delineated linguistically, as well as an international dimension generated through publications in key journals such as Gender and Society, European Journal of Women's Studies, Social Politics and Women's Studies International Forum. Mainstream migration journals, such as Journal of Ethnic and Migration Studies, International Migration, and International Migration Review have also carried an increasing number of articles on gender and migration and related topics such as transnational care and families.

English dominates intellectual exchanges. For example, French-language scholars are read as long as they publish in English. Morokvasic (1984) introduced the first major special issue on Women and Migration in International Migration Review in 1984 and she published a number of articles in English in New Community (subsequently renamed Journal of Ethnic and Migration Studies) (1993) and Feminist Review (2004). On the other hand, her articles in the French-language or less well known Eastern European journals are less cited (Morokvasic 2013). A more recent development is for migration and social science journals in other major languages to publish some of their articles in English (Cortes and Oso 2017).

Though there had been earlier publications, a clear interest in women and migration started to emerge in major journals and books in the 1980s, concerned with making women more visible in the study of migration (Kofman et al. 2000). At the time, these studies ranged widely over different countries and encompassed internal migration (Bunster and Chaney 1985; Chant 1992) which was displaced progressively by the focus on the international dimension. By the 1990s, research began to engage with existing migration theories, in particular the neo-classical, the structural and the more recent actor-structure or structuration which was considered more propitious to providing the base of a better understanding of gender and migration. Interestingly, in the first handbook of gender and migration (Willis and Yeoh 2000), edited by two geographers, many of the chapters explored a range of theoretical, empirical and policy issues in the Global South, and often from a development perspective. Indeed, the example of Southern Africa (Wright 1995) was used to illustrate gender and migration theory. The article concluded that structuration theory and its inclusion of human agency, which had emanated from western industrial societies, now provided the most appropriate theory in understanding migration in Southern Africa. It should also be noted that structuration theory was applied to migration from Asia (Goss and Lindquist 1995) so that the experiences of migration in and from the South gave rise to theoretical conceptualisations relating to labour migration, 
households and social reproduction. In this decade, Castles and Miller (1993) had listed the feminization of migration as the fourth trend in the contemporary age of migration. The UN had published for the first time in 1998 global data disaggregated by gender for the period 1960-1990. It was extended in 2002 for the period from 1990 to 2000 (Zlotnik 2003).

The 2000s marked a watershed in that a series of theoretical developments within broader global and transnational paradigms connecting people and places would begin to shape the research agenda and move attention to receiving societies and how they were being affected by global and gendered migration flows of reproductive labour (Kofman 2014). Sassen (2000), a major scholar of global migrations, conceptualised these South to North flows of domestic and sex workers as counter geographies pertaining to the narrative of globalization and global cities (Sassen 2002). Another major conceptual framework for the global transfer of labour was global chains of care (Hochschild 2000), defined as 'a series of personal links between people across the globe, based on the paid or unpaid work of caring'. The concept rapidly became very influential and popular among female migration scholars (Herrera 2013; Lutz 2010) in Europe and the US to analyse recourse to migrant labour largely from the South, or subsequently from poorer countries in Europe (Lutz and Pallenga-Möllenbeck 2012, to fill deficits of domestic and care work in the households (Parreñas 2001). As the chain moved downwards to countries of origin, and where care needs were filled by family members or urban migrants, its value diminished. Most significantly the operation of the chain in the South initially paid scant attention or acknowledged the diversity of family forms and strategies families adopted for the care of children and older people. In more recent years, researchers came to explore the diverse responses to the departure of family members and return across different regions in the South (Hoang et al. 2015; Mazzucato 2015). In comparing different regions they began to take into account variations of care practices in space and over a person's lifetime, also enabling our understanding of the impact of migration to go beyond simplistic notions of unchanging familial and gender relations and producing a truly transnational conceptualisation. Needless to say, large-scale comparative studies require resources and funding usually obtained from research funding agencies in the North (Mazzucato and Dito 2018).

Transnationalism too provided an attractive conceptual tool for those interested in transcending the rigidity of the nation-state as a unit of analysis to embrace the diversity of material, social and symbolic exchanges between places. Yet initially gender was not sufficiently incorporated into it, leading a number of feminist scholars to engender it and explore whether gender relations were reproduced or transformed in the context of transnationalism. Mahler and Pessar (2001) and Pessar and Mahler (2003) put forward a framework based on 'gendered geographies of power', consisting of scale, social location and the agency people have over their social location. A body of research on transnational families has also become more significant in Europe (Bryceson and Vuorela 2002; Bryceson 2019; Freznosa-Flot and Ricordeau 2017) as well as East and South East Asia (Yeoh 2014). Asian researchers too have been prominent in the field of marriage migration using the concept of global hypergamy (Constable 2005), in which reproductive 
labour and marriage migration in Asia parallel and articulate with each other (Kofman 2012; Lan 2008; Piper and Roces 2003).

The other theoretical approach that has become an almost obligatory reference is intersectionality which had originated in Black feminism and coined by Kimberley Crenshaw (1989) in an attempt to theorize intersecting identities and sources of oppression. Thus the aim was to address the gaps in both feminist and anti-racist discourses concerning the experiences of women of colour with discrimination in the workplace and with domestic abuse. It has been claimed to be the most important theoretical contribution that women's studies has made so far (McCall 2005, p. 1771). The concept travelled rapidly to Europe (Davis 2019) and has been extensively used by migration scholars to capture the inequalities, discrimination and the complexity of diversity (Oso and Ribas-Mateos 2013). As Davis (2019) notes it is very popular in the Global North but much less so in the Global South. The concept needs to be deployed transnationally, engaging different forms of power relationships between and within the Global North and South (Asis et al. 2019).

What I have sought to do in this paper is to suggest the ways we might explore qualitative aspects of how an epistemic community is configured and the unequal power relations through which its networks operate in the production of knowledge, in particular its theoretical nodes. I used the emergence and development of gender and migration to illustrate my points. As the epistemic community of gender and migration expanded and consolidated, it has done so primarily in the Global North in comparison to an earlier period at the end of the twentieth century of a more diffuse constellation of studies and theory development. As indicated in the Between Fragmentation and Institutionalisation Paper, the greatest intensity of co-authorship has probably been within Europe, although as we have seen, theories have emanated from the US and travelled rapidly to Europe. While East and South East Asia in particular have come to play a more prominent part in pushing forward the field of gender and migration (Choi and Peng 2016; Lan 2008, 2018), and creating its own 'multipolar, decentered ways of knowledge production' (Xiang 2013), its contribution has still not received the attention it deserves (Asis et al. 2019). So although the gender and migration epistemic community has been extended geographically, its internationalisation is uneven and with significant regions in the South on the theoretical margins.

\footnotetext{
Acknowledgements

I would like to thank Anastasia Christou and Parvati Raghuram for suggesting further readings on engaging with Southern knowledge.
}

\section{Author's contributions}

The author read and approved the final manuscript.

Competing interests

The author declares that she has no competing interests.

Received: 1 May 2020 Accepted: 1 June 2020

Published online: 02 October 2020

References

Asis, M., Piper, N., \& Raghuram, P. (2019). From Asia to the world: "Regional" contributions to global migration research. Revue Européenne des Migrations Internationals, 35(1-2), 13-37.

Bryceson, D. (2019). Transnational families negotiating migration and care life cycles across nation-state borders. Journal of Ethnic and Migration Studies, 45(16), 3042-3064.

Bryceson, D., \& Vuorela, U. (Eds.) (2002). The transnational family: New European frontiers and global networks. Oxford: Berg.

Bunster, X., \& Chaney, L. (1985). Sellers and servants: Working women in Lima Peru. New York: Praeger.

Castles, S., \& Miller, M. (1993). The age of migration (1st ed.). Basingstoke: Palgrave Macmillan. 
Chant, S. (1992). Gender and migration in developing countries. Chichester: Belhaven.

Choi, S. Y. P., \& Peng, Y. (2016). Masculine compromise: Migration, family and gender in China. Berkeley: University of California Press. Connell, R. (2014). Rethinking gender from the south. Feminist Studies, 40(3), 518-539.

Constable, N. (2005). Cross-border marriages: Gender and mobility in transnational Asia. Philadelphia: University of Pennsylvania Press.

Cortes, A., \& Oso, L. (2017). Birds of a feather in transnational flight: Return, gender and mobility/immobility between Ecuador and Spain. Revista Española de Sociologia, 26(3), 1359-72.

Crenshaw, K. (1989). Demarginalizing the intersection of race and sex. A black feminist critique of antidiscrimination doctrine, feminist theory and antiracist politics. The University of Chicago Legal Forum, 140, 139-167.

Davis, K. (2019). Who owns intersectionality? Some reflections on feminist debates on how theories travel. European Journal of Women's Studies on line. https://doi.org/10.1177/1350506819892659.

De Sousa Santos, B. (2014) Epistemologies of the South: Justice Against Epistemicide, Abingdon: Routledge.

Freznosa-Flot, A., \& Ricordeau, G. (Eds.) (2017). International marriages and marital citizenship. Southeast women on the move. Abingdon: Routledge.

Goss, J., \& Lindquist, B. (1995). Conceptualizing labor migration: A structuration approach. International Migration Review, 29(2), 317-351.

Halvorsen, S. (2018). Cartographies of epistemic expropriation: Critical reflections on learning from the south. Geoforum, 95, 11-20.

Herrera, G. (2013). Gender and international migration: Contributions and cross fertilizations. Annual Review of Sociology, 39, $471-489$.

Hoang, L. A., Lam, T., Yeoh, B., \& Graham, E. (2015). Transnational migration, changing care arrangements and left-behind children's responses in south-east Asia. Children's Geographies, 13(3), 263-277.

Hochschild, A. R. (2000). Global care chains and emotional surplus value. In W. Hutton, \& A. Giddens (Eds.), On the edge: Living with global capitalism (pp. 130-146). London: Sage.

Kofman, E. (2012). Rethinking care through social reproduction. Articulating circuits of migration. Social Politics, 19(1), 142-162.

Kofman, E. (2014). Reviewing theories of gender and migration: Perspectives from Europe and North America. In G. Battistella (Ed.), Global and Asian perspectives on international migration (pp. 119-138). Heidelberg: Springer.

Kofman, E., Phizacklea, A., Raghuram, P., \& Sales, R. (2000). Gender and international migration in Europe. London: Routledge.

Lan, P. C. (2008). New global politics of reproductive labor: Gendered labor and marriage migrations. Sociology Compass, 2(6), 1801-1815.

Lan, P. C. (2018). Raising global families: Parenting, immigration, and class in Taiwan and the US. Redwood City: Stanford University Press.

Levy, N., Pisarevskaya, A., \& Scholten, P. (2020). Between fragmentation and institutionalization: The rise of migration studies as a research field. Comparative Migration Studies, 8. https://doi.org/10.1186/s40878-020-00180-7.

Lutz, H. (2010). Gender in the migratory process. Journal of Ethnic and Migration Studies, 36(10), 1647-1663.

Lutz, H., \& Pallenga-Möllenbeck, E. (2012). Care workers, care drain and care chains: Reflections on care, migration and citizenship. Social Politics, 19(1), 15-37.

Mahler, S., \& Pessar, P. (2001). Gendered geographies of power: Analyzing gender across transnational spaces. Identities: Global Studies in Culture and Power, 7(4), 441-459.

Mazzucato, V. (2015). Transnational families and the well-being of children and caregivers who stay in origin countries. Social Science and Medicine, 132, 208-214.

Mazzucato, V., \& Dito, B. (2018). Transnational families: Cross-country comparative perspectives. Population, Space and Place, 24(7), e2165.

McCall, L. (2005). The complexity of intersectionality. Signs, 30(3), 1771-1800.

Morokvasic, M. (1984). Birds of passage are also women. International Migration Review, 18(4), 886-907.

Morokvasic, M. (2013). Transnational mobilities and gender in Europe. Ars and Humanitas Studje, 7(2), 45-59.

Oso, L., \& Ribas-Mateos, N. (2013). An introduction to global and development perspective: A focus on gender, migration and transnationalism. In L. Oso, \& N. Ribas-Mateos (Eds.), The international handbook on gender, migration and transnationalism. Cheltenham: Edward Elgar.

Parreñas, R. S. (2001). Servants of globalization: Women, migration and domestic work. Stanford: Stanford University Press.

Pessar, P., \& Mahler, S. (2003). Transnational migration: Bringing gender in. International Migration Review, 37(3), 812-846.

Piper, N., \& Roces, M. (Eds.) (2003). Wife or worker? Asian women and migration. New York: Rowman and Littlefield.

Quijano, A. (2000). 'Coloniality of power, Eurocentrism and Latin America'. Nepantla, 1(3), 533-580.

Raghuram, P., \& Madge, C. (2006). Towards a method for postcolonial development geography? Possibilities and challenges. Singapore Journal of Tropical Geography, 27(3), 270-88.

Sassen, S. (2000). Women's burden: counter geographies of globalization and feminization of survival. Journal of International Affairs, 5392, 503-524.

Sassen, S. (2002). Global cities and survival circuits. In B. Ehrenreich, \& A. Hochschild (Eds.), Global woman. Nannies, maids and sex workers in the new economy. Metropolitan Books.

Truong, T. D. (1996). Gender, international migration and social reproduction: Implications for theory, policy research and networking. Asian and Pacific Migration Journal, 5(1), 47-52.

Willis, K, \& Yeoh, B. (Eds.) (2000). Gender and migration. Cheltenham: The International Library of Studies of on Migration, Edward Elgar.

Wright, C. (1995). Gender awareness in migration theory: Synthesising actor and structure in southern Africa. Development and Change, 26, 771-791.

Xiang, B. (2013). Return and the ordering of transnational mobility in Asia. In B. Xiang, B. Yeoh, \& M. Toyota (Eds.), Return: nationalizing transnational mobility in Asia (pp. 1-20). Durham: Duke University Press.

Yeoh, B. (2014). Engendering international migration: Perspectives from within Asia. In G. Battistella (Ed.), Global and Asian perspectives on international migration (pp. 139-152). Heidelberg: Springer.

Zlotnik, H. (1995). Migration and the family: Some female perspectives. Asian and Pacific Migration Journal, 4(2-3), 253-271.

Zlotnik, H. (2003). The global dimensions of female migration. Migration Information Source https://www.migrationpolicy.org/ article/global-dimensions-female-migration/.

\section{Publisher's Note}

Springer Nature remains neutral with regard to jurisdictional claims in published maps and institutional affiliations. 